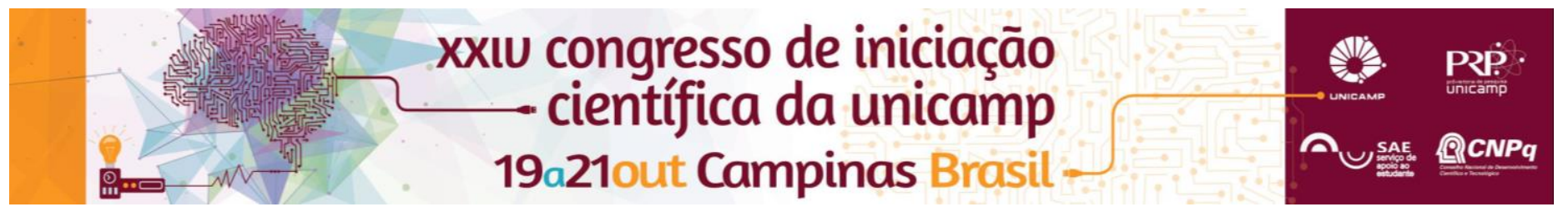

\title{
Tradução comentada do The Book of Repulsive Women
}

\section{Beatriz Regina Guimarães Barboza}

\section{Resumo}

Com base na discussão sobre a situação historiográfica do livro The Book of Repulsive Women, primeira publicação de Djuna Barnes em 1915, a pesquisa apresenta as possíveis razões de sua escassa apreciação pela crítica e a tradução comentada dos poemas. Para isso, será ponderado o gesto de trazer à tona uma obra que se tornou desconhecida muito em parte por escolha da própria autora.

\section{Palavras-chave:}

tradução, poesia americana, Djuna Barnes.

\section{Introdução}

Realizar uma tradução comentada do livreto The Book of Repulsive Women é um ato de afronta, na medida em que consideramos a opinião de Philip Herring, o principal biógrafo de Djuna Barnes. Ele afirmou que se alguém realmente se importasse com Djuna Barnes, pouco diria sobre este livreto, pois a própria autora e seus amigos teriam desejado que os poemas nunca tivessem sido publicados $\left(1995\right.$, p. 88) ${ }^{1}$. O motivo, à primeira vista, teria sido a caracterização abjeta da vida lésbica nos versos que constituíram a primeira obra publicada da autora, mas que ecoavam uma perspectiva pessimista sobre a vida em geral. No entanto, o ódio da autora por seus versos de 1915 talvez seja a crueza com que ela mesma via explícitos os fantasmas de sua vida neles e dos quais buscava escapar como forma de sobrevivência, como reconhecido por Herring na biografia sobre Djuna (1995, p. 306) ao observar que, ao fim da vida, Djuna ainda compunha poemas de imagens tão horríveis quanto os daquele primeiro livro. Assim, a luta de Djuna contra a publicação deste livreto tenha sido uma tentativa de autodefesa - inclusive, a autora era conhecida pela excessiva proteção de sua intimidade contra seus leitores e contra si própria, possivelmente, sendo intolerável ver nos seus poemas o reflexo de suas concepções mais enraizadas. Apesar de seu motivo ser válido enquanto indivíduo, o valor de sua obra transcende-a, e desrespeitá-la é posicionar-se contra essa reclusão psicológica; um ato pelo qual me responsabilizei nesta pesquisa.

\section{Resultados e Discussão}

Concebida na perspectiva da Teoria Literária, a pesquisa obteve uma tradução satisfatória dos versos de Djuna Barnes em respeito à sua forma e conteúdo, a partir da versão de $2003^{2}$, comparando-a com anteriores.

O livro apresenta uma estrutura fixa, usando o metro de balada e os pentâmetros iâmbicos, embora a autora realize deslizes, pois seus oito poemas são chamados por ela de 8 rhythms. Após análise rítmica pelo sistema de syllable-stress verse utilizando as teorias de Derek Attridge $^{3}$, pude trabalhar com 0 sistema de correspondências funcionais das formas literárias em poesia, conforme proposta por Paulo Henriques Britto ${ }^{4}$ (2008, p. 25), reconhecido tradutor do inglês.

A Teoria Literária, por sua vez, abriu espaço para uma discussão de temática comparada, reconhecendo a proximidade entre Djuna Barnes e Charles Baudelaire, o que influenciou a busca pelo tom na tradução da obra.

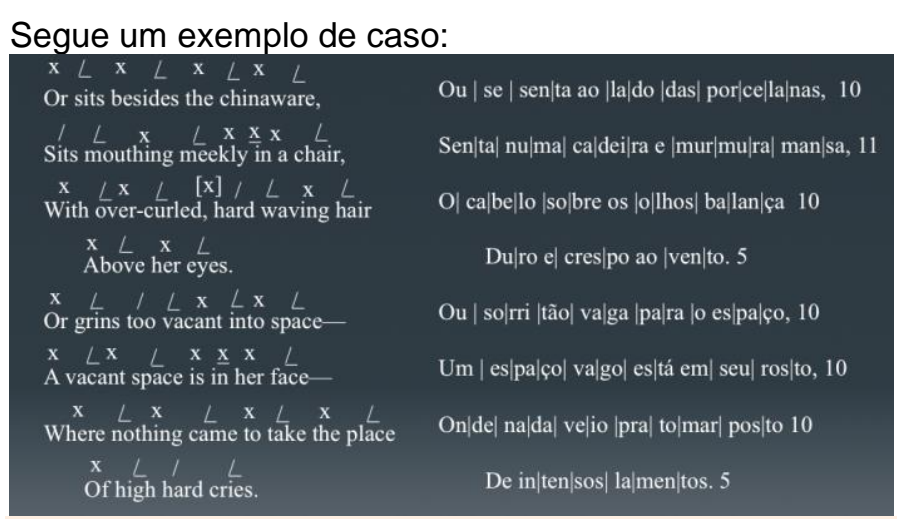

\section{Conclusões}

$\mathrm{Na}$ íntegra da pesquisa, creio ter apresentado justificativas suficientes para embasar minhas escolhas tradutórias. Para tanto, os comentários foram indispensáveis, articulando as informações contidas nos poemas com a forma na qual eles foram escritos. Neles, ficou clara a forma como Djuna trabalhava com ritmos consagrados na poesia, mas com frequência recorrendo às infrações, sendo este o seu método de intervenção. Demonstrava, assim, que seu estilo irônico, até de pastiche, apresentava a degradação das mulheres lésbicas, principalmente, dentro do contexto de falsa emancipação da época. Assim, esta pesquisa pôde servir de incentivo à divulgação da obra de Duna Barnes no Brasil, explorando as suas temáticas, imagens e estilo, assim como servir de experiência para reflexão aos Estudos da Tradução sobre a tradução de versos em inglês no metro de balada e dos pentâmetros iâmbicos ao português.

\section{Agradecimentos}

Agradeço ao CNPq, Conselho Nacional de Desenvolvimento Científico e Tecnológico - Brasil, pelo apoio financeiro à realização deste trabalho.

${ }^{1}$ HERRING, Philip. Djuna: The Life and Work of Djuna Barnes. New York: Penguin Books, 1995.

${ }^{2}$ BARNES, Djuna. The Book of Repulsive Women and other poems. Manchester: Carcanet Ltd., 2003.

${ }^{3}$ ATTRIDGE, Derek. Poetic Rhythm: an introduction. Cambridge: Cambridge University Press, 1996.

${ }^{4}$ BRITTO, Paulo Henriques. "A tradução para o português do metro de balada inglês”, In: Fragmentos, no. 34. Florianópolis, 2008. 